\title{
Food allergy in the first 6 months of life - clinical aspects
}

\author{
Mirela Ionela Stocklosa' ${ }^{1}$ Irina Dijmarescu ${ }^{2,3}$, Gabriela Lesanu,2,3, Cristina Becheanu ${ }^{2,3}$, \\ Daniela Pacurar ${ }^{2,3}$, Coriolan UImeanu ${ }^{2,3}$ \\ 1"Dr. Ion Cantacuzino" Clinical Hospital, Bucharest, Romania \\ 2"Grigore Alexandrescu" Emergency Clinical Hospital for Children, Bucharest, Romania \\ 3"Carol Davila" University of Medicine and Pharmacy, Bucharest, Romania
}

\begin{abstract}
Introduction. Food allergies are increasingly more frequent all over the world, in most cases with childhood onset. Cow's milk protein allergy (CMPA) is the most frequent allergy in infants. Clinical manifestations are nonspecific and can affect the skin, digestive tract, respiratory system or can be systemic. Oral challenge test is the gold standard diagnostic test and the treatment is the exclusion diet.

Material and method. Between June 2014 and December 2017 we conducted a prospective study in which 179 infants were included. They had been hospitalized in the Pediatrics Department of "Grigore Alexandrescu" Emergency Clinical Hospital for Children with suggestive symptoms for food allergy before the age of 6 months.

Results. The final study group consisted of 161 infants, because in 18 cases food allergy was excluded. $95 \%$ of infants had cow's milk protein allergy (CMPA). The average age of the symptom's onset was 2.3 months. $27.2 \%$ of infants had acute allergic reaction like moderate-severe forms of acute urticaria or Quincke oedema (angioedema). $2 / 3$ of infants from the study group had late clinical manifestation of CMPA: vomiting (32.3\%), food refusal $(30.4 \%)$, bloody stools (27.3\%) and poor weight growth (34.1\%). Approximately one third of the infants associated moderatesevere forms of gastroesophageal reflux, unresponsive to treatment. $48 \%$ of infants had IgE mediated cow's milk protein allergy and $52 \%$ had non-IgE mediated allergy. Only $41 \%$ of infants from the group study were exclusively breastfed at 3 months of age and one third of them had an acute allergic reaction when a milk formula was introduced. Cow's milk protein introduction after the exclusion diet was made at 9,6 months for the breastfed group and at 13 months for the group fed with formula.

Conclusions. Food allergy diagnosis requires a high degree of suspicion from the pediatrician, as the predominant gastro-intestinal symptoms are non-specific and non-IgE mediated. The nutrition in the first months of life has an important impact in allergic diseases.
\end{abstract}

Keywords: infant, cow milk allergy, acute allergic reaction, late allergic reaction, digestive manifestations

\section{INTRODUCTION}

Food allergy has become a public health issue because of the rising prevalence around the world. Most of the food allergies have the onset in childhood.

In infants, the most frequent food allergy is cow's milk protein allergy (CMPA) [1,2]. This allergy affects $1.9-4.9 \%$ of infants [3] and the incidence among the breastfed infants is $0.5 \%$ [4].

This type of allergy is a result of cow's milk protein hypersensitivity and these reactions are secondary to the alteration of immune tolerance due to allergenic foods. These events are reproductible, triggered by the allergen exposure and the mechanisms are IgE mediated, non-IgE mediated or combined [1]. The most frequent antigens for CMPA are lactoglobuline ( $\alpha$-lactoglobuline, $\beta$-lactoglobuline) and casein (special $\alpha$ s1-casein, $\alpha$ s- 2 casein, $\beta$ casein and $\kappa$-casein). The persistent forms of CMPA are associated with high titers of $\alpha$ s- 1 casein and $\beta$-casein IgE antibody [5]. The type of allergic mechanism has a prognostic role in the allergy evolution. Non-IgE mediated allergies go in remission earlier than the IgE forms.

Usually, the symptoms of CMPA have the onset in the first year of life. The clinical manifestations in 
CMPA are non-specific and can affect the cutaneous systems, the gastro-intestinal tract, the respiratory system or can be systemic. Regarding the time of allergen ingestion and the moment of symptoms onset, the allergic reactions are immediate (the clinical manifestations develop from minutes to 2 hours) or late onset (the symptoms appear beyond 2 hours to days from ingestion) [6]. The immediate reactions are $\operatorname{IgE}$ mediated. The systemic reactions represent $1-2 \%$ of cases [7].

Most of the gastrointestinal symptoms have a nonIgE mechanism. There are described some particular forms of non- $\operatorname{IgE}$ mediated food allergies which has different evolution and prognosis (table 2).

An interesting aspect in CMPA is the association with the gastroesophageal reflux disease (GERD). Gastroesophageal reflux is a frequent motility disorder in early childhood and affects approximately $10 \%$ of infants. It is reported that $40-50 \%$ of GERD are associated with CMPA [12]. Also, the severe forms of GERD have CMPA [16].

In infants, in most of the cases, the clinical history, the symptoms and the clinical examination are not enough to establish the CMPA diagnosis. Food allergies have a wide phenotypic variability. Laboratory investigations in vivo (skin prick tests) and in vitro (cow's milk protein IgE antibody) are not accurate. Positive results indicate food sensitization and the immune mechanism of the allergy. A negative test does not exclude the allergy. The infants with gastrointesti- nal symptoms have predominant negative serological tests. The gold standard diagnostic test remains the oral challenge test.

CMPA treatment consist in the exclusion of the cow's milk protein from infant's or mother's diet (milk, yogurt, cheese, butter). Overall, the CMPA prognosis is good.

\section{MATERIAL AND METHOD}

Between June 2014 and December 2017, we conducted a prospective study in which 179 infants were included. They had been hospitalized in the Pediatrics Department of "Grigore Alexandrescu" Emergency Clinical Hospital for Children with suggestive symptoms for food allergy.

The study group consisted of 179 infants aged below 6 months with onset of suggestive food allergy symptoms. They were examined, laboratory tests were performed and then they were monitored during exclusion diet. Anthropometric data, personal and familial history of atopy, symptoms, test results (cow's milk protein IgE, level of hemoglobin, presence of eosinophilia, immunoglobulin test) were recorded in the personal file. The follow-up consults were made at 1, 3, 6, 9, 12, 18 and 24 months. The study's results were processed using Microsoft Excel and SPSS program. Chi-square test was used to detect statistical correlations $(\mathrm{p}<0.05$ was consider significant statistically). Also, the Kolmogorov-Smirnov and Shapiro-

TABLE 1. Food allergy immediate and late onset clinical manifestations [8]

\begin{tabular}{|c|c|c|}
\hline $\begin{array}{l}\text { Cutaneous } \\
\text { symptoms }\end{array}$ & $\begin{array}{l}\text { Immediate reactions } \\
\text { IgE mediated } \\
\text { Late onset reactions } \\
\text { Non-IgE mediated }\end{array}$ & $\begin{array}{l}\text { Urticaria } \\
\text { Angioedema } \\
\text { Oral allergy syndrome } \\
\text { Atopic dermatitis } \\
\text { Herpetic dermatitis } \\
\text { Contact dermatitis }\end{array}$ \\
\hline $\begin{array}{l}\text { Gastrointestinal } \\
\text { symptoms }\end{array}$ & $\begin{array}{l}\text { Immediate reactions } \\
\text { IgE mediated } \\
\text { Late onset reactions } \\
\text { Non-IgE mediated }\end{array}$ & $\begin{array}{l}\text { Nausea, vomiting, abdominal pain, diarrhea } \\
\text { Vomiting, regurgitations, food refusal, diarrheic stools, bloody stools, } \\
\text { constipation, colic, abdominal pain, constipation, poor weight gain }\end{array}$ \\
\hline $\begin{array}{l}\text { Respiratory } \\
\text { symptoms }\end{array}$ & $\begin{array}{l}\text { Immediate reactions } \\
\text { IgE mediated } \\
\text { Late onset reactions } \\
\text { Non-IgE mediated }\end{array}$ & $\begin{array}{l}\text { Rhino-conjunctivitis } \\
\text { Cough } \\
\text { Wheezing } \\
\text { Rhinorrhea } \\
\text { Chronic cough } \\
\text { Wheezing }\end{array}$ \\
\hline Anaphylaxis & Severe systemic reaction & $\begin{array}{l}\text { Rapid onset with congestion, pruritus, angioedema } \\
\text { Dyspnea, stridor, Wheezing } \\
\text { Hypotension } \\
\text { Hypotonia } \\
\text { Syncope }\end{array}$ \\
\hline
\end{tabular}


TABLE 2. Clinical forms of food allergies depending on pathogenic mechanism [9]

\begin{tabular}{|c|c|c|c|}
\hline Mechanism & Clinical form & Characteristics & Prognosis \\
\hline IgE mediated & $\begin{array}{l}\text { Urticaria } \\
\text { Angioedema }\end{array}$ & & \\
\hline \multirow[t]{3}{*}{$\begin{array}{l}\text { non-lgE } \\
\text { mediated }\end{array}$} & Food protein enteropathy & $\begin{array}{l}\text { - onset in the first months of life } \\
\text { - chronic diarrhea and failure to thrive } \\
\text { - sometimes mild-moderate anemia and } \\
\text { hypoproteinemia } \\
\text { - mimics the celiac disease }\end{array}$ & Resolve in $1-2$ years $[11,12]$ \\
\hline & Food protein proctocolitis & $\begin{array}{l}\text { - onset in the first months of life (usually at } 2 \text { months of } \\
\text { age) [10] } \\
\text { - bloody stools, mucous stools } \\
\text { - well appearance } \\
\text { - lack of the systemic symptoms } \\
\text { - normal weight gain }\end{array}$ & $\begin{array}{l}\text { Develop immune tolerance by } 12 \\
\text { months of life [13] }\end{array}$ \\
\hline & Food protein enterocolitis & $\begin{array}{l}\text { - onset }<9 \text { months } \\
\text { - repetitive vomiting, usually associated with diarrhea, } \\
\text { dehydration, and weight lose } \\
\text { - can be confused with sepsis }\end{array}$ & $\begin{array}{l}\text { Prognosis is variable: resolution by } \\
2 \text { years in } 35 \% \text { of cases [14], } 90 \% \\
\text { of cases [15] until } 5 \text { years }\end{array}$ \\
\hline Mixt mechanism & $\begin{array}{l}\text { Eosinophilic esophagitis } \\
\text { Eosinophilic gastritis } \\
\text { Atopic dermatitis }\end{array}$ & $\begin{array}{l}\text { - affects any age } \\
\text { - predominant male } \\
\text { - vomiting, regurgitations, food refusal, dysphagia, } \\
\text { abdominal pain, food impaction, failure to thrive } \\
\text { - requires histological confirmation }\end{array}$ & $\begin{array}{l}\text { - chronic evolution } \\
\text { - complication: stenosis, } \\
\text { dysmotility }\end{array}$ \\
\hline
\end{tabular}

Wilk tests were used to establish data's normal distribution.

\section{RESULTS}

CMPA was excluded in 18 infants considering the results of the blood tests, evolution under exclusion diet and the oral challenge test. The final study group consisted in 161 infants with food allergy with onset of symptoms before 6 months of age.

Most of the cases were from the urban area with an urban: rural ratio of $4: 1$.

In the study group $47 \%$ of the infants were male and $53 \%$ female. The average age at onset of symptoms was 2.3 months with standard deviation by 1.6 months. The average diagnostic age was 4.5 months. The average time since the onset of symptoms until established diagnosis was 2.1 months with a standard deviation by 3.8 months.

In this group, only $16 \%$ of infants had a sibling with a form of allergy.

The main food allergy in the study group was cow's milk protein allergy (about $95 \%$ of the cases), rest of them had allergic reaction due to mother's allergenic food ingestion (fish, peanuts).

The cutaneous and gastrointestinal symptoms were the main clinical presentation. The most fre- quent symptoms were the gastrointestinal ones (figure 1). We reported only 6 cases of food allergy with respiratory symptoms (about 3\% of infants). No anaphylactic reaction was recorded in our group.

$27.2 \%$ of infants had immediate symptoms, which occurred in the first 2 hours after ingestion of the allergenic food. The main symptoms in these cases were moderate-severe acute urticaria $(27 \%)$ and Quincke edema ( $8 \%)$.

$2 / 3$ of infants had late onset symptoms of CMPA. The most frequent were gastrointestinal symptoms: vomiting (32.3\%), food refusal (30.4\%), regurgitations $(17.3 \%)$, bloody stools $(27.3 \%)$, mucous stools $(32.9 \%)$, diarrhea $(12.4 \%)$ and poor weight gain (34.1\%). These symptoms were characterized by recurrence and persistence. We reported a statistical correlation between late onset reactions and symptoms like regurgitations $(\mathrm{p}=0.03)$, food refusal $(\mathrm{p}=$ $0.01)$, bloody stools $(p=0.005)$, mucous stools $(p=$ $0.001)$ and poor weight gain $(\mathrm{p}=0.025)$.

At this age, $28 \%$ of infants with CMPA had gastroesophageal reflux disease. We reported a high statistical correlation between infants with late onset symptoms and GERD $(p=0.01)$. These cases had moderate-severe gastroesophageal reflux disease diagnosed by contrast radiologic exam and were unresponsive to treatment. 


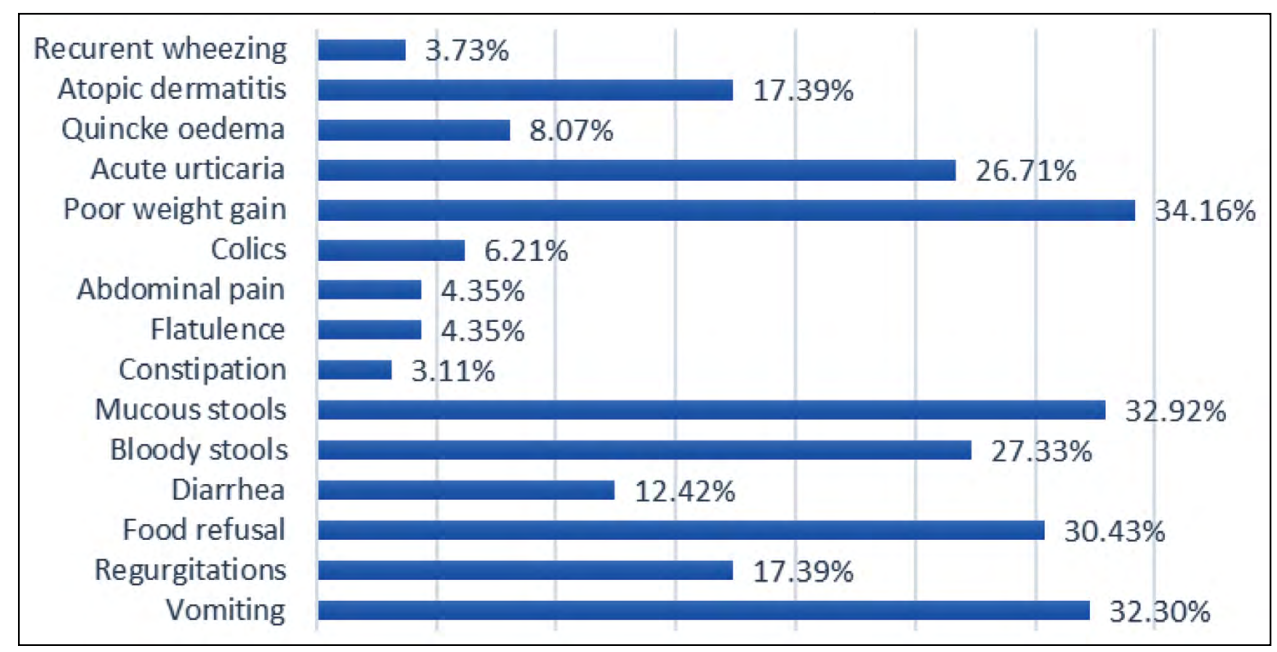

FIGURE 1. Clinical manifestation of food allergy in infants

$48 \%$ of infants had IgE mediated allergies and the rest of 52\% had non-IgE mediated food allergies. We looked up for correlations between clinical manifestations and the value of cow's milk protein IgE-antibody. We observed that infants with negative results of specific IgE-s had a statistically significant higher frequency of bloody stools. Also, we noticed that infants with positive IgE-s had a statistically significant higher frequency of symptoms like urticaria and angioedema. We reported a statistical correlation between recurrent wheezing and positive cow's milk protein IgE-antibody.

Only $41 \%$ of infants were exclusively breastfed at the age of 3 months, the rest of $59 \%$ of infants were mixt or formula fed. In this study, 19 infants had an immediate allergic reaction when a milk formula was introduced (approximately $43 \%$ of the total immediate reactions). We reported a statistical correlation between introduction of milk formula in the infant diet and the presence of late onset allergy symptoms $(p=0.009) .83 \%$ of infants did not receive solid food.

In time, only $7 \%$ of infants associated other food allergy which were clinically and serological diagnosed. The main food allergens were egg, wheat, peanuts, and soy.

The average time of the exclusion diet was 11.7 months and $8 \%$ of the infants required extended exclusion diet over the 2-year follow-up period. The introduction of cow's milk proteins was performed on average in 9.6 months after exclusion for the exclusively breastfed infants and in 13 months for the formula fed infants. The period of exclusion diet had no relevant statistical distribution; therefore, we used the Mann-Whitney U non-parametric test to analyze if there was a significance difference between breastfed infants and the mixt or formula fed infants. We observed that the period until the infants become toler- ant to cow's milk protein was not influenced by the type of the nutrition.

\section{DISCUSSIONS}

In our study group, the main food allergy in infants was cow's milk protein allergy, which is consistent with recent data from pediatric food allergy studies $[1,2]$. The average age at the onset of allergy symptoms was 2.3 months, while the average diagnostic age was 4.5 months. This difference is due to nonspecific symptoms in infants (regurgitations, vomiting, poor weight gain) and due to predominant late allergic reaction in the group.

Allergic familial history was not statistical significative for the study group, which, in practice, is a very important clue for CMPA.

The clinical manifestations of food allergies are polymorphic. Cutaneous symptoms appear in 50-70\% of cases, about $50-60 \%$ of infants have gastro-intestinal symptoms and the respiratory reactions occurs in $20-30 \%$ of cases [17]. One third of the infants had immediate allergic reactions, predominantly cutaneous manifestations ( $27 \%$ versus $50-70 \%$ in other studies). This difference can be explained by conducting this study in an emergency children hospital, where the moderate-severe and acute urticaria and angioedema were admitted.

$73 \%$ of the infants from this group had late allergic reactions with a high frequency of gastrointestinal symptoms which corelates with the current data. The digestive manifestations are nonspecific, which makes diagnosing CMPA a real challenge. From all the gastro-intestinal symptoms, only bloody stools are a clinical marker of non-IgE mediated CMPA (also similar with recent data).

Recent studies revealed that $40-50 \%$ of children with gastroesophageal reflux disease had CMPA also 
[18]. In our study, we observed that one third of infants had CMPA and gastroesophageal reflux disease. The reflux cases were moderate-severe ones, unresponsive to treatment. This association is important for facilitating a rapid and accurate CMPA diagnosis.

In this study, less than half of the infants were exclusively breastfed and most infants were mixt, or formula fed. Only $8 \%$ of infants required extended exclusion diet over 2 year. Natural history of CMPA's studies have different results: the first cohort studies observed that children became tolerant to cow's milk protein again in about one year [11]. On the other side, newer studies, revealed a lower remission rate: children develop immune tolerance in $50 \%$ of cases by one year of age, $75 \%$ of cases at 3 years old and $90 \%$ of children are cured at 6 years old [19].

The exclusion diet period was shorter for the breastfed infants as compared with formula fed infants, with no statistical significance in our study. We can conclude that in this study the period until immune tolerance was reached was not influenced by the type of nutrition. In the last two decades, the focus of the specialists was on the nutrition intervention in the

\section{REFERENCES}

1. Sicherer SH. Epidemiology of food allergy. J Allergy Clin Immunol. 2011;127:594-602.

2. Rona RJ, Keil T, Summers $C$ et al. The prevalence of food allergy: $A$ meta-analysis. J Allergy Clin Immunol. 2007;120:638-46.

3. Fiocchi A, Brozek J, Schunemann H, Bahna SL, von Berg A, Beyer K, Bozzola M, Bradsher J, Compalati E, Ebisawa $\mathrm{M}$ et al. World allergy organization (WAO) diagnosis and rationale for action against cow's milk allergy (DRACMA) guidelines. World Allergy Organ J. 2010;3:57161.

4. Host A, Husby S, Østerballe O. A prospective study of cow's milk allergy in exclusively breast-fed infants. Acta Paediatr Scand. 1988; 77:663-670.

5. Vila L, Beyer, Sampson HA. Role of conformational and linear epitopes in the achievement of tolerance in cow's milk allergy. Clin Exp Allergy. 2001;31:1599-1606.

6. Koletzko S, Niggemann B, Arato A, Dias JA, Heuschkel R, Husby S, Mearin ML, Papadopoulou A, Ruemmele F.M, Staiano A, Schappi MG, Vandenplas $Y$. Diagnostic approach and management of cow's milk protein allergy in infants and children: ESPGHAN GI Committee Practical guidelines. JPGN. 2012;55:221-229.

7. Järvinen KM, Sicherer SH, Sampson HA, Nowak-Wegrzyn A. Use of multiple doses of epinephrine in food-induced anaphylaxis in children. J Allergy Clin Immunol. 2008;122:133-138.

8. Host A, Halken S. Approach to feeding problems in the infant and young children. Pediatric Allergy. 2016;371-376.

9. Gupta RS. Pathophysiology and symtoms of food allergy and anaphylaxis. Pediatric Food Allergy. 2020;17-29.

10. Leonard SA. Non-IgE-mediated adverse food reactions. Curr Allergy Asthma Rep. 2017;17(12):84.

11. Host A. Cow's milk protein allergy and intolerance in infancy. Some clinical, epidemiological, and immunological aspects. Pediatr Allergy Immunol. 1994;5:1-136.

12. Fiocchi A, Terracciano L, Bouygue GR, Veglia F, Sarratud T, Martelli A, Restani P. Incremental prognostic factors associated with cow's milk allergy outcomes in infant and child referrals: The Milan Cow's Milk prevention of children food allergies. Breastfeeding is the main pillar in food allergy management. Cow's milk protein allergy has a lower incidence in breastfed infants [4]. Also, the duration of breastfeeding has an important influence on the allergic disease risk rate [20-22]. But also, there are numerous studies with a main concern and focus on food allergy prevention. The current guidelines recommend hypoallergenic formula in high risk documented allergy infants, when the breastfeeding is not possible $[23,24]$.

\section{CONCLUSIONS}

Food allergy diagnosis requires a high degree of suspicion from the pediatrician, as the predominant gastro-intestinal symptoms are non-specific and nonIgE mediated. The response to exclusion diet and challenge test remains the main tools of evaluation for allergy in infants. Prevention of CMPA in infants with atopic predisposition is made with hypoallergenic formulas when supplementation is needed. The nutrition in the first months of life has an important impact in allergic diseases onset.

Allergy Cohort Studt. Ann Allergy Asthma Immunol. 2008;101:166173.

13. Lake AM. Food-induced eosinophilic proctocolitis. J Pediatr Gastroenterol Nutr. 2000;30 (Suppl.):S58-60.

14. Ruffner MA, Ruymann K, Barni S, Cianferoni A, Spergel JM. Food protein-induced enterocolitis syndrome: Insights from review of a large refferal population. J Allergy Clin Immunol Pract. 2013;1:343-9.

15. Katz Y, Goldberg MR, Rajuan N, Cohen A, Leshno M. The prevalence and natural course of food protein-induced enterocolitis syndrome to cow's milk: A large-scale, prospective population-based study. J Allergy Clin Immunol. 2011;127:647-53.

16. Nielsen RG et al. Severe gastroesophageal reflux disease and cow milk hypersensitivity in infants and children: disease asociation and evaluation of a new challenge procedure. J Pediatr Gastroenterol Nutr. 2004;39:383-91.

17. Sampson HA, Anderson JA. Summary and recommendations: Classification of gastrointestinal manifestations due to immunologic reactions to foods in infants and young children. J Pediatr Gastroenterol Nutr. 2000;30:S87-S94.

18. Ho MH, Wong WH, Chang C. Clinical spectrum of food allergies: A comprehensive review. Clin Rev Allergy and Immunol. 2014;46:22540.

19. Host A, Halken S, Jacobsen HP et al. Clinical course of cow's milk protein allergy/intolerance and atopic diseases in childhood. Pediatr Allergy Immunol. 2002;13(suppl 15):23-8.

20. Saarinen UM, Kajosaari M. Breastfeeding as prophylaxis against atopic disease: Prospective follow-up study until 17 years old. Lancet 1995;346:1065-1069.

21. Gdalevich M, Mimouni D, David M, Mimouni M. Breast-feeding and the onset of atopic dermatitis in childhood: A systematic review and meta-analysis of prospective studies. J Am Acad Dermatol. 2001; 45:520-527.

22. Snijders BE, Thijs C, Dagnelie PC, Stelma FF, Mommers M, Kummeling I, Penders J, van Ree R, van den Brandt PA. Breast-feeding duration and infant atopic manifestations, by maternal allergic 
status, in the first 2 years of life (KOALA study). J Pediatr. 2007;151:347-351.

23. von Berg A, Filipiak-Pittroff B, Kramer U, Hoffmann B, Link E, Beckmann C, Hoffmann U, Reinhardt D, Grubl A, Heinrich J, Wichmann HE, Bauer CP, Koletzko S, Berdel D; GINIplus study group. Allergies in high-risk schoolchildren after early intervention with cow's milk protein hydrolysates: 10-year results from the German Infant Nutritional Intervention (GINI) study. J Allergy Clin Immunol. 2013; 131:1565-1573.
24. Muraro A, Halken S, Arshad SH, Beyer K, Dubois AE, Du Toit G, Eigenmann PA, Grimshaw KE, Høst A, Lack G, O'Mahony L,

Papadopoulos NG, Panesar S, Prescott S, Roberts G, de Silva D, Venter C, Verhasselt V, Akdis AC, Sheikh A; EAACI Food Allergy and Anaphylaxis Guidelines Group: EAACl food allergy and anaphylaxis guidelines. Primary prevention of food allergy. Allergy. 2014;69:590601. 